\title{
Invited Address
}

\section{The development of the New Zealand vegetable seed industry and future opportunities}

\author{
J. MCKAY \\ South Pacific Seeds (NZ) Ltd \\ P.O. Box 113, Methven, New Zealand \\ nzoffice@spsnz.co.nz
}

\begin{abstract}
Vegetable seed has been produced in New Zealand for over a century. In the late 1900s the potential for global trade was realised and Canterbury has become the major area of vegetable seed production in New Zealand. The main species involved are onion, baby leaf vegetables, sweet corn and brassica. Squash, capsicum, tomato, lettuce and telegraph cucumber are also important. This paper outlines the development of the vegetable seed industry in New Zealand and suggests that future requirements to meet increasing demand for high quality seed will be irrigation and mechanisation.
\end{abstract}

\section{Introduction}

The first settlers brought seeds and root stock material to New Zealand. They recognised the importance of useful vegetable plant material. In these early days vegetable producers propagated their own seed to maintain a seed supply. Some selection may have been possible but real genetic improvement would have been negligible. Seeds were also imported from England and Australia, but, these were often not suited to New Zealand conditions. Eventually some small seed shops were established, the most famous being Yates and Coopers Seeds.

Englishman Arthur Yates was the second son of Samuel Yates. Samuel Yates' father had started a business in seeds at Stockport near Manchester in England in 1826. Arthur Yates migrated to New Zealand as a teenager. After working for 3 years on farms in the Otago and Gisborne districts, Arthur
Yates established a seed business in Auckland in 1883 at 40 Victoria Street. In 1887 he left his brother, Ernest, to manage the New Zealand operation and opened a branch in Sydney. In 1906 the two brothers reached an amicable agreement to separate the two companies and run them as two independent companies. From a small seedsman shop with one employee and sales on the first day of trading of 15 cents they steered the development of the New Zealand business. Yates became the most recognised name in New Zealand vegetable growing and gardening, with 'Yates Reliable Seeds' as their slogan.

Some years earlier, in 1841, 6 year old Frederick Cooper arrived with his family on the ship Oriental at the struggling settlement of Wellington. The 40 hour week was 100 years away and pioneers had only one way to survive: hard work and long hours. Frederick Cooper became interested in gardening and by 1860 had opened a nursery in Wellington at the top end of Taranaki Street. He soon found seeds from England were not always suitable and began developing his own strains. The name of ' $\mathrm{F}$ Cooper Ltd' and the reputation of 'Coopers Seeds' spread throughout New Zealand. Good seeds were able to help farmers who were developing the country to obtain bigger and better yields of vegetables from the same acreage. Coopers was at one time the largest seed house in New Zealand, producing and exporting pea, vegetable, flower and fodder seeds.

In 1974 F Cooper Ltd was sold to Arthur Yates \& Co Ltd. The Yates Seed Division 
was sold to South Pacific Seeds in 2003 and the sales brand name for commercial growers changed to Terranova Seeds. Terranova Seeds is still the largest vegetable seed supplier in New Zealand.

\section{Vegetable Seed Production in New Zealand}

Farming to produce vegetable seeds in New Zealand has been important from the early days. Early seed production areas were Central Otago, Blenheim and the Wairarapa.

In Central Otago a Government Station 'The Moa Seed Farm' located in the Teviot Valley, southeast of Roxborough, produced significant volumes of seed after the First World War. Truck loads full of sacks of parsnip, carrot and beetroot seeds were a common sight during the harvest season. A roadside restaurant and lodge called 'The Seed Farm' still operates on the site today. Blenheim and the Wairarapa continue to produce limited quantities of vegetable seed today, but, as a result of the advent of irrigation systems and the presence of progressive and innovative seed production companies, Canterbury has become the major area of vegetable seed production in New Zealand.

Seeds from plant breeders in the northern hemisphere have become important to the global vegetable seed industry. The seeds produced were the result of intensive plant breeding and selection by specialist companies. A number of famous brands, such as 'Sluis and Groot', developed from farmers whose hobby was selecting to improve existing seed lines. 'Sluis and Groot' was started by two farmers from Holland. From these very small beginnings in northeast Holland S\&G as it is now known has its own permanent seed production specialist in New Zealand. S\&G is owned by multinational company Syngenta and is one of the bigger players globally in the seed trade.

Following the Second World War cross breeding or 'hybrid' seed production was developed for many species. This development was not confined only to Europe, companies from Japan, Asia and America also developed hybrids. Hybrid seeds are the result of intensive selection and cross breeding programs. F1 or hybrid seeds can be likened to the process of cross breeding in livestock. The resultant seeds are vigorous, true to type, have even and fast growth, produce higher quality produce for the supermarket shelf and can enable continuous supply of product over a long season. For example, a cauliflower grower who planted two hectares needed to have a large workforce to go through the crop two times per week to cut the heads as they were ready. Hybrid seed now enables the crop to be planted as five row plots with separate plots planted over a number of weeks. Each plot matures evenly at the same time with every head the same size, shape and colour, enabling complete harvest of each sowed plot, at regular intervals through the season. These systems can be used to reduce labour greatly as mechanical harvesting may be possible. Also the product can attract a higher price.

\section{The New Zealand Vegetable Seed Industry}

The vegetable seed industry in New Zealand today is made up of a small amount of breeding (including some onions, pumpkin and vining peas), sales of seed to commercial growers and seed production.

Some international and some local companies are undertaking new breeding in New Zealand. The items being worked on here include onion, vining peas, pumpkin, and potatoes.

There are approximately ten companies in the market, selling seeds to fresh market growers. The big players are Seminis (the largest vegetable seed company in the world and owned by Monsanto), Terranova Seeds, South Pacific Seed Sales, Premier Seeds and Lefroy Valley Seeds. Seeds sold to commercial growers are almost totally 
hybrid seeds. The main crop species sold in New Zealand are onion, baby leaf vegetables (using seeds of lettuce, Asian leafy vegetables of Mizuna, Mabuna, Tatsoi and spinach), sweet corn and brassica (cabbage, cauliflower and increasing rapidly broccoli). Other important species are squash, capsicum, tomato, lettuce and telegraph cucumber.

Vegetable seed production occupies a niche position, but nonetheless is a major business for agriculture in New Zealand. It largely fits into the arable farming scene as irrigation, fertile soils, farmer expertise, seed drying, handling and harvesting machines are required. A number of seed production companies undertake various vegetable seed production work today. The vast majority of this work is carried out for the export market.

One of the pioneers of this work was $\mathrm{Mr}$ Ross Smith who worked for Hodder and Tolley Ltd in the early 1980s. His main role there was to sell ryegrass seed into Europe. However on the way to Europe he would call in to Thailand as there was a customer to whom he sold around 100 tonnes of marrowfat peas. There he saw many new types of leafy vegetables and as he was a keen gardener, the following year he purchased seeds of 5 or 6 types of these vegetables to try in his vegetable garden. In his garden they looked nothing like the tropical leafy vegetables he had seen at the Bangkok market - they all remained small and went quickly to seed. This was the beginning of the modern era of New Zealand's export vegetable seed production. Ross Smith subsequently went on to form Smith Seeds as a specialist company producing, in particular, seeds of the openpollinated varieties of these vegetables for the Asian markets, something they continue to do successful today.

Around 1990, Chris Green of the fledgling Midlands Seed Company made enquiries in Europe for some higher-value crops for specialist seed production. From many enquiries he received only one reply. $\mathrm{He}$ subsequently visited $\mathrm{Mr}$ Beemsterboer of Bejo a large family company breeding vegetables. Bejo is the world's largest producer and supplier of carrot seed and now uses Midlands Seed Ltd as their New Zealand seed production arm.

Around the same time, South Pacific Seeds Pty Ltd, an Australian-based specialist hybrid vegetable seed production company came to New Zealand looking for a cooler climate and longer day length to produce the spinach seed the company had been unsuccessful at producing on the mainland of Australia and in Tasmania. South Pacific Seeds employed a Ministry of Agriculture and Fisheries arable manager and adviser, David Montgomery, to show them around Canterbury and Marlborough. Subsequently we undertook trials of spinach and radish on our farm for them. We then had the opportunity to join a new company, South Pacific Seeds New Zealand. South Pacific Seeds New Zealand began in 1983 with 7 crops. Today this specialist vegetable seed company works with over 230 farmers to produce over 400 mostly hybrid vegetable seed crops.

\section{Why New Zealand and what of the future?}

Today seeds are recognised as a tool to bring global food security to markets.

The traditional areas for growing vegetable seed crops (of the kind we can produce here) are South China, Japan, Korea, Italy, France, Denmark and the United States of America. These countries all have land mass at latitude $43^{\circ}-44^{\circ}$. To produce seed in the counter season (the northern hemisphere winter) you need to look to the southern hemisphere. At the latitude required there are only three places to go, the South Island and lower North Island of New Zealand, Tasmania and Southern Chile (which is very wet and not suitable for seed production). All the rest is ocean. There is only one place to go - New Zealand. 
New Zealand is unique and valuable to the international vegetable seed production scene. Our reliability is recognised internationally. We have long cool springs, good farmers, good soils and irrigation systems, good quarantine coupled with a lack of established wild vegetable species and a stable government. There is a lot of upside to our potential here. New Zealand has a global location. This is a huge plus for vegetable seed production industry here.

World vegetable consumption is increasing at a rate of approximately $7 \%$ per year. To satisfy the demand of increasing population in developing nations and increased consumption of vegetables everywhere New Zealand will in the future be asked to produce more of the same vegetable seed crops. Essential to this will be more irrigation development in seed production areas, increased mechanisation to reduce labour costs and attracting more farmers to this work in the new areas. Quality will be the key. New crops will also be needed, e.g., corn salad (or lambs lettuce), bunching onion and Japanese parsley.
Our research institutes have some real possibilities to help our ability to supply world demand through the development of new technologies. The work of John Hampton's Smart Seeds team at Lincoln University, in collaboration with experts from other institutions, on a number of ground-breaking technologies is a good example. I believe these are likely to give a significant edge to New Zealand produced seeds in the future.

Another issue will be competitive costs of production, especially for developing country markets. Continually increasing quality and finding ways to do that will be important.

In summary, the vegetable industry has a niche in New Zealand's agriculture. It is needed by the people on this planet and will make an increasing contribution to our economy. It will challenge our resources and our resolve to grow and enhance the industry. But the opportunity is there. Let's take it. 